\title{
Effect of Dietary Onion, Garlic and Fenugreek Seeds Powder on Feed Intake, Blood Metabolites and Rumen Fermentation in Ossimi Ewes
}

\author{
Abu EL-Kassim, M.A. ' ;.A. Abd El-Hafez ${ }^{2}$; S.M. Mousa ${ }^{2}$ and E.H. Hassan ${ }^{1}$ \\ ${ }^{1}$ Animal Production Department, Faculty of Agriculture, Al-Azhar University Assiut, Egypt. \\ ${ }^{2}$ Animal Production Department, Faculty of Agriculture, Assiut University, Egypt.
}

Received on: $23 / 4 / 2018$

Accepted for publication on: 10/5/2018

\section{Abstract}

This study was carried out to evaluate the effect of onion, garlic, fenugreek seeds as feed additives on feed intake, some blood plasma constituents and ruminal fermentation of ossimi ewes. Twenty pregnant ossimi ewes on day $90 \pm 7$ of pregnancy, were randomly divided into four similar groups ( 5 animals each). Control group (T1) was fed the basal diet which consisted of $60 \%$ concentrate feed mixture (44\% yellow corn, $20 \%$ soybean meal, $20 \%$ wheat bran, $13 \%$ undecorticated cottonseeds meal, $2 \%$ lime stone and 1\% salt) and $40 \%$ roughages (20\% wheat straw and $20 \%$ chopped alfalfa hay). While, the other three treatment groups were fed the same basal diet, supplemented with either 3\% onion powder (T2), 3\% garlic powder (T3) or 3\% fenugreek seeds powder (T4) the rations (concentrate + roughages) were fed ad lipitum. Feed intake was recorded daily. Blood samples were collected from the jugular vein from all animals before morning feeding. Rumen samples were collected from all ewes using a stomach tube to determine ruminal $\mathrm{pH}$ values, ammonia-N concentration and total VFA s concentration.

Feed intake increased $(\mathrm{P}<0.05)$ during the late pregnancy of ewes fed onion, garlic and fenugreek seeds. While, after parturition feed intake was not significantly differ among groups except for that of onion and garlic groups at the first month of lactation, which was significantly $(\mathrm{P}<0.05)$ increased as compared with control. Plasma total protein and albumin levels increased $(\mathrm{P}<0.05)$ in treated groups as compared with control, while there were no significant differences in plasma globulin, albumin: globulin ratio, triglycerides and glucose between treated groups and control one. Plasma cholesterol concentration decreased $(\mathrm{P}<0.05)$ in ewes fed garlic as compared with those fed control, onion and fenugreek diets. Also, plasma cholesterol concentration of ewes fed onion decreased $(\mathrm{P}<0.05)$ as compared with fed control and fenugreek diets. There were no significant differences among groups in rumen $\mathrm{pH}$ values at zero $\mathrm{h}$ of feeding or 6 hrs after feeding. Ruminal ammonia-N concentration decreased $(\mathrm{P}<0.05)$ in all treated groups as compared with control. Also, total volatile fatty acids concentration in rumen liquor increased $(\mathrm{P}<0.05)$ in all treated groups as compared with control one. In conclusion onion, garlic or fenugreek seeds as feed additives may have a beneficial effect on feed intake, blood metabolites and rumen fermentation of ossimi ewes.

Keywords: onion, garlic, fenugreek, ewes. 


\section{1- Introduction}

Medicinal plants were used for various purposes such as traditional medicine, industrial applications and food preservatives. In the last two decades substantial increase in use of herbs and their products not only as herbal medicinal products, but also as feed additives. Herbs and spices could be used in animal nutrition, to replace the use of antibiotics (after the ban of antibiotics in 2006). Medicinal plants contain various chemical substances such as polyphenols, quinines, flavonols /flavonoids, alkaloids, polypeptides or their oxygensubstituted derivatives (Cowan, 1999 and Negi, 2012). For example onion (Allium cepa) is the most widely cultivated Allium contains a heart stimulant, increases pulse volume and frequency of systolic pressure and coronary flow. Onion consumption lowers blood sugar, lipids and cholesterol (Mittal et al., 1974). Garlic (Allium sativum) is the second most widely cultivated Allium after onion. Garlic oil contains several compounds, including sulfur compounds (thiosulfinates, allyl sulfides, glutamylcysteines, allicin), enzymes, free amino acids, sterols, steroids, triterpenoid glycosides, flavonoids, phenols and organoselenium compounds (Reuter and Sendl, 1994). Also, it has biological activities such as cholesterol lowering properties as reported by numerous studies (Reuter and Sendl, 1994 and Adler and Holub, 1997) as well as, significant lowering blood pressure (Silagy and Neil, 1994).

Fenugreek (Trigonella foenumgraecum) is such an herb and a member of the legume family, found in India, Middle East, North Africa and
South Europe. It is used as a natural herbal medicine to promote lactation in lactating women. It has also been shown to have a positive effect on lactation performance in ruminants such as dairy cows, water buffaloes and dairy goats (Kholif \& El-Gawad, 2001).

Therefore the objective of this trail was to evaluate the effect of onion, garlic, fenugreek seeds as feed additives on feed intake, some blood plasma metabolites and ruminal fermentation parameters of ossimi ewes.

\section{2- Material and Methods}

\section{2-1- Animals and rations}

This study was conducted at the research farm of Animal Production Department, Faculty of Agriculture, Al-Azhar University, Assiut, Egypt, during the period from 2014 to 2016. Twenty pregnant Ossimi ewes on day $90 \pm 7$ of pregnancy till four months after parturition, with an average live body weight of $52.50 \pm 2.5 \mathrm{~kg}$ and 14 -18 months old. Animals were randomly divided into four similar groups (5 animals each). The control ration (T1) consisted of $60 \%$ concentrate feed mixture (CFM) and 40\% roughages. Concentrate feed mixture (CFM) (consisted of 44\% yellow corn, $20 \%$ soybean meal, $20 \%$ wheat bran, $13 \%$ undecorticated cottonseeds meal, 2\% lime stone and 1\% salt) and roughages (consisted of $20 \%$ wheat straw and $20 \%$ chopped alfalfa hay). The treated rations were the same control ration plus $3 \%$ of either onion powder (T2), garlic powder (T3) or fenugreek seeds (T4). The ewes were fed ad libitum and the daily rations were offered two times /day on 9 am and $2 \mathrm{pm}$. Residuals (if found) were 
recorded every day for daily feed intake calculation. Feed ingredient samples were analyzed for dry matter, ash, crude protein, crud fiber and ether extract according to methods of AOAC (1990). The chemical composition of the ingredients is shown in Table (1).

Table 1. Chemical composition of control and supplemented rations fed to ewes

\begin{tabular}{|l|c|c|c|c|}
\hline \multirow{2}{*}{ Feed nutrients } & \multicolumn{4}{|c|}{ Treatments* } \\
\cline { 2 - 5 } & $\begin{array}{c}\text { Control } \\
\text { (T1) }\end{array}$ & $\begin{array}{c}\text { Onion } \\
\text { (T2) }\end{array}$ & $\begin{array}{c}\text { Garlic } \\
\text { (T3) }\end{array}$ & $\begin{array}{c}\text { Fenugreek } \\
\text { (T4) }\end{array}$ \\
\hline Dry matter & 92.58 & 92.58 & 92.58 & 92.58 \\
\hline Organic matter & 86.78 & 86.78 & 86.78 & 86.78 \\
\hline Ash & 5.80 & 5.80 & 5.80 & 5.80 \\
\hline Crude protein & 13.90 & 14.10 & 14.10 & 14.10 \\
\hline Crude fiber & 19.74 & 19.74 & 19.74 & 19.85 \\
\hline Ether extract & 2.71 & 2.71 & 2.71 & 2.71 \\
\hline NFE & 50.42 & 50.22 & 50.22 & 50.21 \\
\hline
\end{tabular}

*Control $=$ control ration, consisted of $60 \%$ and $40 \%$ roughages; Onion $=$ control ration supplemented with $3 \%$ onion powder, Garlic $=$ control ration supplemented with $3 \%$ Garlic powder and Fenugreek $=$ control ration supplemented with $3 \%$ fenugreek seeds powder.

\section{2-2- Sampling and Analysis of Blood Plasma}

Blood samples were collected from the jugular vein from all animals before morning feeding. Blood samples were directly collected into clean dried glass culture tubes with EDTA (Ethylene Diamine Tetra Acetic Acid) which work as anticoagulant then centrifuged at 4000 r.p.m. for 20 minutes; blood plasma was then separated into a clean dried glass vial and stored at $-18^{\circ} \mathrm{C}$ till chemical analysis. Spectro-photometric determination of plasma total protein, albumin, cholesterol, triglycerides and glucose were done according to the methods described by Cannon (1974), Beng and Lim, (1973), Burtis et al., (2006), Scheleter and Nussel (1975) and Howanitz and Howantiz (1984) respectively. Globulin concentrations (g/dl) were calculated by the subtraction of Albumin from Total protein.

\section{2-3- Rumen liquor}

Rumen samples were collected from ewes using a stomach tube.
Samples were taken three times monthly after parturition before morning feeding and $6 \mathrm{hrs}$ after feeding. Rumen liquor samples were filtrated through 3 layers of cheese cloth. Rumen $\mathrm{pH}$ values were immediately determined after collection of rumen liquor using digital $\mathrm{pH}$ meter (Beckman, model 45, USA). Strained rumen liquor was stored in glass bottles $(100 \mathrm{ml})$ with few drops of toluene and paraffin oil just to cover the surface and stored at a deep freeze ($18^{\circ} \mathrm{C}$ ) till chemical analysis. Ruminal ammonia-N concentration was determined according to Konitzer and Voigt (1963) and total VFA s concentration was determined according to Warner (1964).

\section{2-4- Statistical Analysis}

The experimental design followed was complete randomized design. Data were statistically analyzed using general linear model (G.L.M) procedure of S.A.S (2002). For blood parameters, the following model was used $\mathrm{Yij}=\mu+\mathrm{Ti}+\mathrm{Eij}$ 
Where, Yij $=$ experimental observation, $\mu=$ general mean, $\mathrm{Ti}=$ the effect of treatment, $\mathrm{i}=\mathrm{T} 1, \mathrm{~T} 2, \mathrm{~T} 3$ and $\mathrm{T} 4$ and $\mathrm{Eij}=$ the errors related to individual observation.

Feed intake and rumen liquor parameters data were analyzed according to the following statistical model.

$\mathrm{Y}_{\mathrm{ijk}}=\mu+\mathrm{T}_{\mathrm{i}}+\mathrm{B}_{\mathrm{j}}+(\mathrm{TB})_{\mathrm{ij}}+\mathrm{E}_{\mathrm{ijk}}$.

Where, $\mathrm{Y}_{\mathrm{ijk}}=$ experimental observations, $\mu=$ general mean, $\mathrm{Ti}=$ the effect of treatment, $i=\mathrm{T} 1, \mathrm{~T} 2, \mathrm{~T} 3$ and $\mathrm{T} 4, \mathrm{Bj}=$ the effect of time rumen liquor and milk sampling, (TB $)_{\mathrm{ij}}$ $=$ interaction between time and treatments and $\mathrm{E}_{\mathrm{ijk}}=$ the errors related to individual observation. Significant differences were determined by Duncan's Multiple Range test (Duncan, 1995).

\section{3- Results and Discussion}

\section{3-1- Feed intake}

Results of feed intake are presented in two different stages (Table 2). The first one is the last two months of the pregnant period (the fourth and fifth months) at which feed intake increased significantly $(\mathrm{P}<0.05)$ in onion, garlic and fenugreek groups as compared with control one. In the fourth month of pregnant the increase in feed intake was $7.63,6.25$ and $5.55 \%$ for onion, garlic and fenugreek respectively while, the corresponding values for fifth month were $8.74,7.11$ and $7.79 \%$. While, after parturition (the second period) feed intake did not show any change due to treatments except for the first month in which feed intake was significantly $(\mathrm{P}<0.05)$ increased in onion and garlic as compared with control but the differences among treated groups (onion, garlic and fenugreek) were not significant. In the first month the rate of increase was $5.57 \%, 4.93 \%$ and $2.75 \%$ in onion, garlic and fenugreek respectively.

These results are in harmony with the results obtained by Abo EINor et al. (2007) who found that fenugreek seeds and lepidium sativum increase $(\mathrm{P}<0.05)$ feed intake in pregnant buffaloes. Also, Lin et al. (2013) who found that dry matter intake of roughage increase significantly $(\mathrm{P}<0.05)$ by adding essential oils to sheep ration. As well as, Kholif et al. (2012) who studied the effect of garlic, cinnamon and ginger oils on the performance of dairy goats and found that dry matter intake was increased in treated groups. The increase of feed intake in onion and garlic groups may be due to that aromatic plants (onion and garlic) contain various chemical substances which improve the nutrients palatability (Kholif et al., 2012 and Hassan and Abdel-Raheem, 2013) While, the increase in feed intake in fenugreek might be partially due to the presence of saponins in fenugreek seeds which increase food consumption and also, fenugreek seeds had an effect on hypothalamus to stimulate hungriness center in the brain and increase the desire for eating (Petit et al., 1993).

In contrast to current results some authors found no effect of using garlic on sheep feed intake Klevenhusen et al. (2011) and lactating goats Mirzaei et al. (2011). This disagreement may be due to differences in type of diets or to the different in dose of garlic. 
Table 2. Effect of onion, garlic, fenugreek seeds as feed additives on feed intake by ewes (kg/day)

\begin{tabular}{|c|c|c|c|c|c|}
\hline \multirow{2}{*}{$\begin{array}{c}\text { Physiological } \\
\text { stage }\end{array}$} & Periods & \multicolumn{5}{|c|}{ Treatments* } \\
\cline { 2 - 7 } & (month) & $\begin{array}{c}\text { Control } \\
\text { (T1) }\end{array}$ & $\begin{array}{c}\text { Onion } \\
\text { (T2) }\end{array}$ & $\begin{array}{c}\text { Garlic } \\
\text { (T3) }\end{array}$ & $\begin{array}{c}\text { Fenugreek } \\
\text { (T4) }\end{array}$ \\
\hline \multirow{3}{*}{ Pregnant } & 4 th & $1.440 \pm 0.006^{\mathrm{b}}$ & $1.550 \pm 0.021^{\mathrm{a}}$ & $1.530 \pm 0.012^{\mathrm{a}}$ & $1.520 \pm 0.017^{\mathrm{a}}$ \\
\cline { 2 - 7 } & $5 \mathrm{th}$ & $1.475 \pm 0.003^{\mathrm{b}}$ & $1.600 \pm 0.029^{\mathrm{a}}$ & $1.580 \pm 0.003^{\mathrm{a}}$ & $1.590 \pm 0.009^{\mathrm{b}}$ \\
\hline \multirow{4}{*}{ Lactation } & $1 \mathrm{st}$ & $1.560 \pm 0.023^{\mathrm{b}}$ & $1.647 \pm 0.026^{\mathrm{a}}$ & $1.637 \pm 0.035^{\mathrm{a}}$ & $1.603 \pm 0.020^{\mathrm{ab}}$ \\
\cline { 2 - 7 } & $2 \mathrm{nd}$ & $1.503 \pm 0.089$ & $1.567 \pm 0.044$ & $1.537 \pm 0.015$ & $1.550 \pm 0.029$ \\
\cline { 2 - 7 } & $3 \mathrm{rd}$ & $1.473 \pm 0.068$ & $1.510 \pm 0.038$ & $1.460 \pm 0.006$ & $1.490 \pm 0.023$ \\
\cline { 2 - 7 } & 4 th & $1.488 \pm 0.009$ & $1.520 \pm 0.055$ & $1.475 \pm 0.044$ & $1.510 \pm 0.03$ \\
\hline
\end{tabular}

${ }^{\mathrm{c}}$ The same letter within a row means no significant difference.

*Control $=$ control ration, consisted of $60 \%$ and $40 \%$ roughages ; Onion $=$ control ration supplemented with 3\% onion powder, Garlic =control ration supplemented with 3\% Garlic powder and Fenugreek $=$ control ration supplemented with $3 \%$ fenugreek seeds powder.

\section{3-2 Blood parameters}

Plasma total protein and albumin level increased significantly $(\mathrm{P}<0.05)$ in treated groups (onion, garlic and fenugreek) as compared with control one with no significant differences among treated groups (Table 3).

The highest value of plasma total protein was recorded in ewes fed onion $(7.185 \pm 0.123)$ followed by those fed garlic $(7.107 \pm 0.066)$ then those fed fenugreek $(6.992 \pm 0.076)$. Plasma albumin concentration increased by $11.6,9.3$ and $7.7 \%$ due to diets supplemented with onion, garlic and fenugreek seeds, respectively. Similarly, Khattab et al.(2010) reported that serum total protein and albumin concentrations were increased $(\mathrm{P}<0.05)$ in lactating buffaloes fed ration supplemented with garlic and fenugreek seeds. Also, Khattab et al.(2011) found that pregnant buffaloes fed rations supplemented with black seed oil had higher $(\mathrm{P}<0.05)$ plasma total protein and albumin than those fed control diet. The increase in plasma total protein in treated groups (onion, garlic and fenugreek) in our study may be due to the increase of crud protein digestibility.

Plasma globulin and albumin: globulin ratio was not significant differ between treated groups and control one (Table 3). These results are in agreement with the results obtained by Abo EI-Nor et al. (2007) found that fenugreek seeds and lepidium sativum had no effect on globulin or albumin: globulin ratio in lactating buffaloes. Also, Biricik et al.(2016) found no effect of adding carvacrol or thymol essential oils to Merino ewes ration on globulin or albumin: globulin ratio. Also, no significant effect due to treatments on blood plasma triglycerides and glucose concentration (Table 3). Similarly, ELGhousein. (2010) found no effect of chamomile flowers and Nigella sativa seeds on glucose, and triglycerides in lactating sheep. Also, Khattab et al. (2011) showed that black seed oil had no significant effect on triglycerides and glucose concentrations in pregnant buffaloes.

Plasma cholesterol concentration decreased $(\mathrm{P}<0.05)$ in ewes fed garlic compared with those fed control, onion and fenugreek diets. Also, 
plasma cholesterol concentration decreased significantly $(\mathrm{P}<0.05)$ in ewes fed onion as compared with those fed control diets however there was no significant difference between onion and fenugreek or between fenugreek and control group. These results are in agreement with the results obtained by EL-Ghousein. (2010) who found that cholesterol concentration decreased significantly $(\mathrm{P}<0.05)$ in lactating sheep fed ration supplemented with chamomile flowers and Nigella sativa seeds Also, Kholif et al.(2012) reported that cholesterol concentration decreased significantly $(\mathrm{P}<0.05)$ in dairy goats fed garlic or ginger essential oils. Similarly, Pirmohammadi et al.(2014) indicated that garlic supplemented-diets resulted in a significant $(\mathrm{P}<0.05)$ decrease of serum cholesterol concentration in pre-partum goats.

Table 3. Effect of onion, garlic, fenugreek seeds as feed additives on blood plasma parameters of ewes

\begin{tabular}{|c|c|c|c|c|}
\hline \multirow{2}{*}{ Items } & \multicolumn{4}{|c|}{ Treatments* $^{*}$} \\
\cline { 2 - 5 } & $\begin{array}{c}\text { Control } \\
(\mathbf{T 1})\end{array}$ & $\begin{array}{c}\text { Onion } \\
(\mathbf{T} 2)\end{array}$ & $\begin{array}{c}\text { Garlic } \\
(\mathbf{T 3})\end{array}$ & $\begin{array}{c}\text { Fenugreek } \\
\mathbf{( T 4 )}^{*}\end{array}$ \\
\hline Total protein (g/dL) & $6.786 \pm 0.093^{\mathrm{b}}$ & $7.185 \pm 0.123^{\mathrm{a}}$ & $7.107 \pm 0.066^{\mathrm{a}}$ & $6.992 \pm 0.076^{\mathrm{a}}$ \\
\hline Albumin (g/dL) & $3.394 \pm 0.056^{\mathrm{b}}$ & $3.788 \pm 0.087^{\mathrm{a}}$ & $3.710 \pm 0.063^{\mathrm{a}}$ & $3.657 \pm 0.088^{\mathrm{a}}$ \\
\hline Globulin (g/dL) & $3.392 \pm 0.100$ & $3.413 \pm 0.096$ & $3.397 \pm 0.064$ & $3.335 \pm 0.107$ \\
\hline Albumin: Globulin (A:G) ratio & $1.048 \pm 0.051$ & $1.128 \pm 0.056$ & $1.109 \pm 0.031$ & $1.126 \pm 0.071$ \\
\hline Cholesterol (mg/dL) & $73.86 \pm 1.205^{\mathrm{a}}$ & $68.97 \pm 1.022^{\mathrm{b}}$ & $65.28 \pm 1.271^{\mathrm{c}}$ & $71.39 \pm 1.227^{\mathrm{a}^{\mathrm{b}}}$ \\
\hline Triglycerides (mg/dL) & $53.05 \pm 1.273$ & $49.86 \pm 1.362$ & $50.45 \pm 1.087$ & $52.59 \pm 1.135$ \\
\hline Glucose (mg/dL) & $84.10 \pm 2.105$ & $84.21 \pm 3.721$ & $88.91 \pm 1.904$ & $84.53 \pm 2.075$ \\
\hline
\end{tabular}

a,b and $\mathrm{c}$ The same letter within a row means no significant difference.

*Control $=$ control ration, consisted of $60 \%$ and $40 \%$ roughages ; Onion $=$ control ration supplemented with $3 \%$ onion powder, Garlic $=$ control ration supplemented with $3 \%$ Garlic powder and Fenugreek $=$ control ration supplemented with $3 \%$ fenugreek seeds powder.

\section{3-3- Rumen fermentation}

Results in Table (4) indicated that rumen liquor $\mathrm{pH}$ values did not affected by either treatments or sampling time. These results are in agreement with the results obtained by Kongmun et al. (2010) they found no effect of adding garlic on $\mathrm{pH}$ values in sheep. Also, Kholif et al. (2012) found no effect of adding garlic or ginger essential oils on $\mathrm{pH}$ values in dairy goats.

Ammonia-N concentrations of rumen liquor are presented in Table (4). Results showed that ammonia-N concentration decreased significantly $(\mathrm{P}<0.05)$ in groups fed onion, garlic and fenugreek as compared with that fed control diet, with no significant differences among treated groups in the first, second and third month. In the first month at $0 \mathrm{~h}$ of feeding ammonia-N reduced by $14.8,14.15$ and $17.8 \%$ due to diets supplemented with onion, garlic and fenugreek seed respectively while, at $6 \mathrm{hrs}$ after feeding the reduction was 10.910 .18 and $16.9 \%$ due to diets supplemented with onion, garlic and fenugreek seed respectively. In the second month the corresponding values at $0 \mathrm{~h}$ of feeding were $11.4,6.88$ and $13.6 \%$ while they were $10.3 \quad 8.05$ and $8.9 \%$ at 6 hrs after feeding. 
Table 4. Effect of onion, garlic, fenugreek seeds as feed additives on Ruminal pH values, Ammonia-N, total volatile fatty acids concentration of ewes

\begin{tabular}{|c|c|c|c|c|c|c|}
\hline \multirow[b]{2}{*}{ parameters } & \multirow[b]{2}{*}{ Month } & \multirow[b]{2}{*}{ Hours } & \multicolumn{4}{|c|}{ Treatments* } \\
\hline & & & $\begin{array}{l}\text { Control } \\
\text { (T1) }\end{array}$ & $\begin{array}{c}\text { Onion } \\
\text { (T2) }\end{array}$ & $\begin{array}{l}\text { Garlic } \\
\text { (T3) }\end{array}$ & $\begin{array}{c}\text { Fenugreek } \\
\text { (T4) }\end{array}$ \\
\hline \multirow{6}{*}{ pH values } & \multirow[b]{2}{*}{1 st } & $\mathbf{0}$ & $6.200 \pm 0.086$ & $6.320 \pm 0.166$ & $6.420 \pm 0.086$ & $6.370 \pm 0.075$ \\
\hline & & 6 & $6.040 \pm 0.081$ & $6.100 \pm 0.170$ & $6.240 \pm 0.075$ & $6.160 \pm 0.098$ \\
\hline & \multirow{2}{*}{2 nd } & $\mathbf{0}$ & $6.180 \pm 0.139$ & $6.280 \pm 0.128$ & $6.380 \pm 0.116$ & $6.400 \pm 0.071$ \\
\hline & & 6 & $5.940 \pm 0.129$ & $6.020 \pm 0.124$ & $6.140 \pm 0.081$ & $6.260 \pm 0.060$ \\
\hline & \multirow{2}{*}{3 rd } & $\mathbf{0}$ & $6.220 \pm 0.162$ & $6.360 \pm 0.172$ & $6.440 \pm 0.160$ & $6.340 \pm 0.157$ \\
\hline & & 6 & $6.060 \pm 0.129$ & $6.080 \pm 0.159$ & $6.300 \pm 0.155$ & $6.100 \pm 0.152$ \\
\hline \multirow{6}{*}{$\begin{array}{c}\text { Ammonia-N } \\
(\mathrm{mg} / \mathrm{dl})\end{array}$} & \multirow[b]{2}{*}{$1 \mathrm{st}$} & $\mathbf{0}$ & $21.83 \pm 0.691^{\mathrm{a}}$ & $18.59 \pm 0.458^{b}$ & $18.74 \pm 0.517^{b}$ & $17.93 \pm 0.296^{b}$ \\
\hline & & 6 & $22.68 \pm 0.711$ & $20.19 \pm 0.431$ & $20.37 \pm 0.306$ & $18.83 \pm 0.431$ \\
\hline & \multirow{2}{*}{2 nd } & $\mathbf{0}$ & $21.57 \pm 0.318^{\mathrm{a}}$ & $19.11 \pm 0.502^{b}$ & $20.09 \pm 0.593^{b}$ & $18.62 \pm 0.699^{b}$ \\
\hline & & 6 & $22.33 \pm 0.304^{\mathrm{a}}$ & $20.09 \pm 0.593^{b}$ & $20.43 \pm 0.756^{b}$ & $20.34 \pm 0.734^{b}$ \\
\hline & \multirow{2}{*}{3 rd } & $\mathbf{0}$ & $21.78 \pm 0.696^{\mathrm{a}}$ & $19.02 \pm 0.950^{b}$ & $19.02 \pm 0.855^{b}$ & $18.94 \pm 0.612^{b}$ \\
\hline & & 6 & $23.18 \pm 0.786^{\mathrm{a}}$ & $21.11 \pm 0.866^{\mathrm{b}}$ & $20.07 \pm 0.795^{b}$ & $20.21 \pm 0.660^{b}$ \\
\hline \multirow{6}{*}{$\begin{array}{c}\text { Total vola- } \\
\text { tile fatty } \\
\text { acids } \\
(\mathrm{meq} / 100 \mathrm{ml})\end{array}$} & \multirow[b]{2}{*}{$1 \mathrm{st}$} & $\mathbf{0}$ & $9.77 \pm 0.354^{b}$ & $11.20 \pm 0.464^{\mathrm{a}}$ & $10.80 \pm 0.539^{\mathrm{a}}$ & $11.70 \pm 0.374^{\mathrm{a}}$ \\
\hline & & 6 & $10.86 \pm 0.424^{b}$ & $12.20 \pm 0.515^{\mathrm{a}}$ & $12.30 \pm 0.332^{\mathrm{a}}$ & $13.00 \pm 0.224^{\mathrm{a}}$ \\
\hline & \multirow{2}{*}{2 nd } & $\mathbf{0}$ & $9.50 \pm 0.224^{b}$ & $12.00 \pm 0.524^{\mathrm{a}}$ & $11.30 \pm 0.700^{\mathrm{a}}$ & $11.40 \pm 0.579^{\mathrm{a}}$ \\
\hline & & 6 & $10.50 \pm 0.232^{b}$ & $12.90 \pm 0.430^{\mathrm{a}}$ & $12.70 \pm 0.632^{a}$ & $12.50 \pm 0.447^{\mathrm{a}}$ \\
\hline & \multirow{2}{*}{3 rd } & $\mathbf{0}$ & $9.900 \pm 0.367^{b}$ & $11.90 \pm 0.510^{\mathrm{a}}$ & $11.80 \pm 0.600^{\mathrm{a}}$ & $11.70 \pm 0.644$ \\
\hline & & 6 & $11.10 \pm 0.292^{b}$ & $13.20 \pm 0.490^{\mathrm{a}}$ & $13.00 \pm 0.447^{\mathrm{a}}$ & $12.80 \pm 0.594^{\mathrm{a}}$ \\
\hline
\end{tabular}

*Control $=$ control ration, consisted of $60 \%$ and $40 \%$ roughages ; Onion $=$ control ration supplemented with $3 \%$ onion powder, Garlic $=$ control ration supplemented with $3 \%$ Garlic powder and Fenugreek $=$ control ration supplemented with $3 \%$ fenugreek seeds powder.

In the third month at $0 \mathrm{~h}$ of feeding the reduction in ammonia-N was $12.67,11.84$ and $13.03 \%$ due to diets supplemented with onion, garlic and fenugreek seed respectively while at $6 \mathrm{hrs}$ after feeding the reduction values were $8.93,13.41$ and $12.81 \%$ due to diets supplemented with onion, garlic and fenugreek seed respectively. These results are in agreement with the results obtained by Hassan and Abdel-Raheem (2013) they found that ammonia-N reduced $(\mathrm{P}<0.05)$ in growing buffalo calves fed rations supplemented with caraway and garlic also, Wang et al. (2009) and Kholif et al.(2012) found that garlic oils reduced $(\mathrm{P}<0.05)$ of ruminal ammonia- $\mathrm{N}$ in sheep and dairy goats respectively. The reduc- tion in ammonia-N concentration in treated groups may be due to inhibit protein hydrolyzing microorganism in the rumen (Patra, 2011).

As shown in Table (4) total volatile fatty acids concentration increased $(\mathrm{P}<0.05)$ in treated groups (T2, T3 and T4) as compared with control one with no significant differences among treatments groups. TVFA'S increase by $17.8 \%, 13.68 \%$ and $23.1 \%$ due to diets supplemented with onion, garlic and fenugreek seed respectively in the first month at $0 \mathrm{~h}$ of feeding while at $6 \mathrm{hrs}$ after feeding the increases were $10.9 \% 10.18 \%$ and $16.9 \%$ due to diets supplemented with onion, garlic and fenugreek seed respectively. In the second month the corresponding values at $0 \mathrm{~h}$ of feed- 
ing were about $26.3,18.9$ and $20 \%$ and at $6 \mathrm{hrs}$ after feeding were 22.8 , 20.9 and $19 \%$. In the third month at $0 \mathrm{~h}$ of feeding the highest value of TVFA was recorded in onion followed by garlic then fenugreek also, the same was observed at $6 \mathrm{hrs}$ after feeding. These results are in agreement with the results obtained by Kholif et al.(2012) they found that concentration of VFAs was higher in dairy goats fed rations supplemented with garlic and ginger oils. Also, Hassan and Abdel-Raheem (2013) reported that total volatile fatty acids concentration increased $(\mathrm{P}<0.05)$ in growing buffalo calves fed rations supplemented with caraway and garlic as a natural feed additives. In this field, Biricik et al. (2016) found that total volatile fatty acids concentrations were increased $(\mathrm{P}<0.05)$ at $3 \mathrm{hrs}$ after feeding in growing sheep by using carvacrol or thymol oils as feed additives. Total volatile fatty acids are the end products of rumen microbial fermentation and represent the main supply of metabolizable energy for ruminants (Van Soest, 1982). Therefore, using onion, garlic and fenugreek as feed additives may be responsible for the improvement of energy production and carbohydrate metabolism in treated groups.

\section{Conclusion}

It could be concluded that onion, garlic or fenugreek seeds as feed additives may have a beneficial effect on feed intake, blood metabolites and rumen fermentation parameters of ossimi ewes.

\section{References}

Abo El-Nor, S.A.H., H.M. Khattab, H.A. Al-Ala my, F.A. Salem and M.M. Abdou, (2007). Effect of Some Medicinal Plants Seeds in the Ra- tions on the Productive Performance of Lactating Buffaloes. Int. J. Dairy Sci, 2: 348-355.

Adler, A.J. and B.J, Holub. (1997). Effect of garlic and fish-oil supplementation on serum lipid and lipoprotein concentrations in hypercholesterolemic men. Anim. J. Clin. Nutr. 65: 445-50.

AOAC (1990). Official Methods of Analysis. 16 Edition. Arlington, VA: AOAC,.

Beng, C.G. and K.L. Lim (1973). Colorimetric determination of albumin in serum. Am. J. Clin. Path., 59:14-21.

Biricik, H., H. H. Oral, A. M. Taluğ, Ş. Ş. Cengiz, M. Koyuncu, and S. Dikmen. (2016). The effects of carvacrol and/or thymol on the performance, blood and rumen parameters, and carcass traits of Merino sheep. Turkish J. Vet. Anim. Sci, 40:651-659.

Bodas, R., N. Prieto, R.García-González, S.Andrés, F. J Giráldeza andS. López. (2012). Manipulation of rumen fermentation and methane production with plant secondary metabolites. Anim. Feed Sci. Technol, 176: 78-93.

Burtis, C.A, E, R. Ashwood and D.E. Bruns (2006). Tietz Textbook of Clinical Chemistry and Molecular Diagnostics. $4^{\text {th }}$ ed., Elsevier Saunders, St. Louis., pp 942- 956.

Cannon, D.C. (1974). Examination of seminal fluid. In: Todd-Sanford Clinical Diagnosis by Laboratory Methods, 31: 1201-1207.

Cowan, M.M. (1999). Plant products as antimicrobial agents. Clin. Microbiol. Rev., 12: 564-582.

Duncan, D.B. (1995). Multiple ranges and multiple F-test.Biometrics., 11: $1-42$.

EL-Ghousein, S. (2010). Effect of some medicinal plants as feed additives on lactating awassi ewe perform- 
ance, milk composition, lamb growth and relevant blood items. Egyptian J. Anim. Prod. 47:37-49.

Hassan, E.H. and S. M. Abdel-Raheem. (2013). Response of Growing Buffalo Calves to Dietary Supplementation of Caraway and Garlic as Natural Additives. World App Sci J, 22 : 408-414.

Howanitz, P.J. and J.H. Howantiz (1984). In: Clinical Diagnosis and Management by laporatory Methods, $17^{\text {th }}$ ed., J.B. Henry, (Ed). W.B. Saunders, Philadelphia, PP. 168.

Khattab. H.M, S.A.H. Abo El-Nor, S.M. Kholif, H.M. El-Sayed,O.H. Abd El-Shaffy and M. Saada.(2011). Effect of different additive sources on milk yield and composition of lactating buffaloes. Lives Sci, 131: 8-14.

Khattab.M. K, A.Z. El-Basiony, S.M. Hamdy and A.A.Marwan.(2011). Immune Response and Productive Performance of Dairy Buffaloes and their Offspring uspplemented with Black Seed Oil. Iran J Appl Anim Sci, 1:227-234.

Kholif, A.M, and M.A.M. Abd-ElGawad, (2001). Medicinal plant seeds supplementation of lactating goats diets and its effects on milk and cheese quality and quantity. Egyptian J. Dairy Sci., 29: 139150.

Kholif. S., M.T.A. Morsy, M.M.Abdo, O.H. Matloup, and A.A.Abu ElElla. (2012). Effect of Supplementing Lactating Goats Rations with Garlic, Cinnamon or Ginger Oils on Milk Yield, Milk Composition and Milk Fatty Acids Profile. J Life Sci, 4: 27-34.

Klevenhusen.F., J.O. Zeitz,S. Duval, M. Kreuzer and C.R. Soliva. (2011). Garlic oil and its principal component diallyl disulfide fail to mitigate methane but improve digestibility in sheep. Anim. Feed

Sci. Technol. 166-167, 356-363.

Kongmun P, M. Wanapat, P. Pakdee, C. Navanukraw and Z.Yu (2011). Manipulation of rumen fermentation and ecology of swamp buffalo by coconut oil and garlic powder supplementation. Livest Sci, 135: 84-92.

Lin.B,Y. lu, A.Z.M. Salem, J.H Wang, Q. Liang, and J.X. Liu, (2013). Effects of essential oil combinations on sheep ruminal fermentation and digestibility of a diet with fumarate included. Anim. Feed Sci. Technol, 184:24-32.

Mirzaei. F., S. Prasad and S. Savar Sofla. (2011). Influence of Medicinal Plants Mixture on Productive Performance Cross Bred Dairy Goats. Curro Res. Dairy Sci. 4 (1): 6-16.

Mittal, M.M., S. Mittal, J.C Sarin,. and M.L. Sharma. (1974). Effect of feeding onion on fibrinolysis, serum cholesterol, platelet aggregation and adhesion. Indian J. Med. Sci. 28:144-153.

Negi, P.S. (2012). Plant extracts for the control of bacterial growth: Efficacy, stability and safety issues for food application. Int. J. Food Microbiol., 156:7-17.

Patra, A. K. (2011). Effects of essential oils on rumen fermentation, microbial ecology and ruminant production. Asian. J. of Anim Vet. Adva, 6: 416-428.

Petit, P., Y. Sauvaire, G.Ponsin, M. Manteghetti, A.Fave, and G.Ribes, (1993). Effects of a fenugreek seed extract on feeding behaviour in the rat: metabolic-endocrine correlates. Pharmacol Biochem Behav, 45:369-374.

Pirmohammadi, R., E. Anassori, Z. Zakeri, and M.Tahmouzi. (2014). Effects of garlic supplementation on energy status of pre-partum Maha- 
badi goats. Vet. Res. Forum., 5: 207-212.

Reuter, H.D. and A.Sendl. (1994). Allium sativum and Allium ursinum: Chemistry, pharmacology and medicinal applications, Econ. Med. Plant Res., 6:56-113.

Scheletter, G. and E. Nussel. (1975). Arbertsmed Sozialmed. Parcuate nucleusuate nucleusentimrd.10:25.

Silagy, C.A. and H.A.Neill. (1994). A meta-analysis of the effect of garlic on blood pressure, J. Hypertens., 12: 463-8.
Van Soest, P.J., (1982). Nutritional Ecology of the Ruminant. 2nd Edn., O and B Books Inc.

Wang, C.J., S.P.Wang, and H. Zhou. (2009). Influence of flavomycin, ropadiar and saponin on nutrient digestibility, rumen fermentation, and methane emission from sheep. Anim. Feed Sci. Technol., 148: 157-166.

Warner, A.C.I. (1964). Production of volatile fatty acids in the rumen methods of measurements. Nut. Abst. and Rev, 34: 339-347. 
تأثير إضافة مسحوق البصل و الثوم وطحين بذور الحلبه المجفف علي الغذاء المأكول ويعض

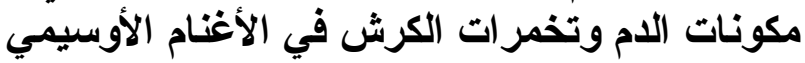

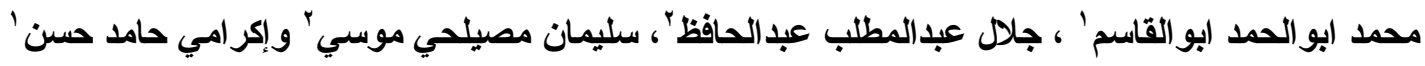

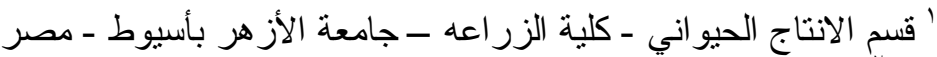

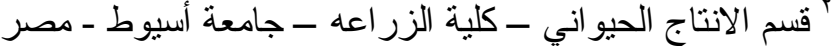

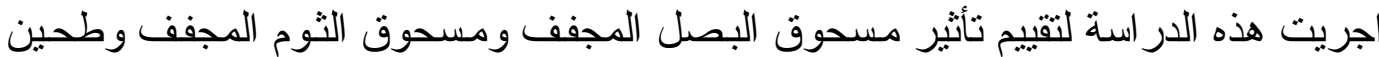

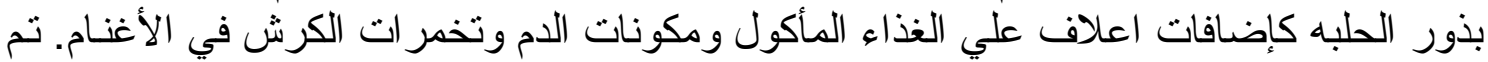

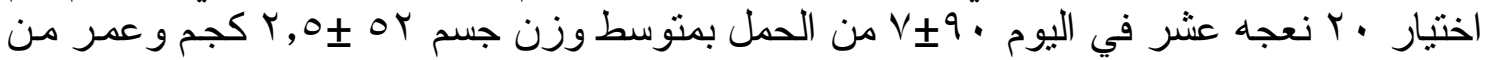

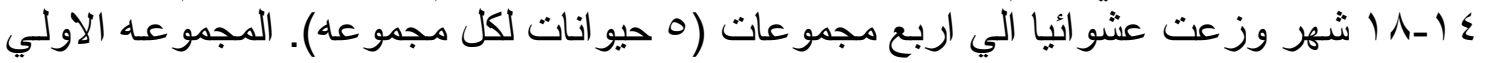

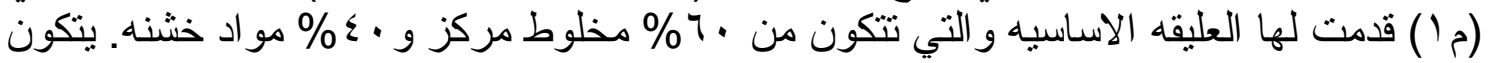

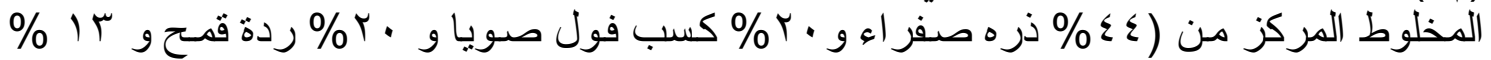

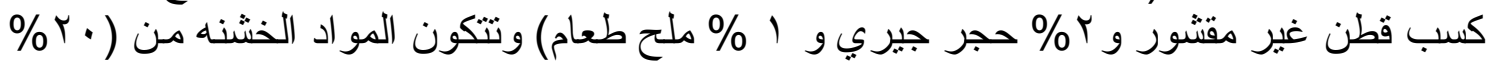

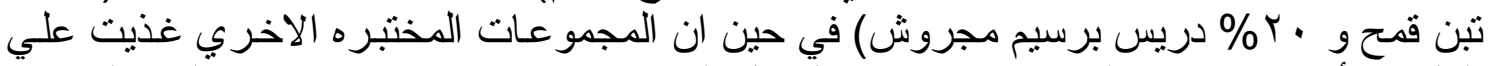

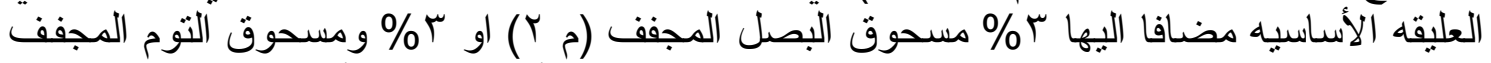

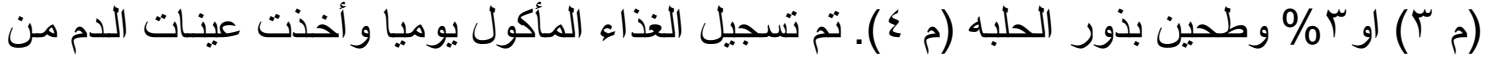

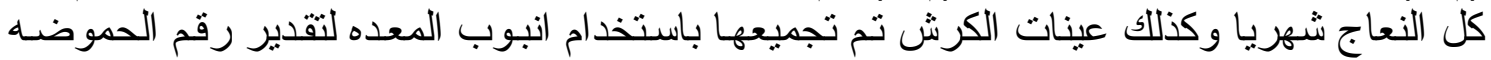

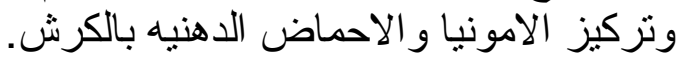

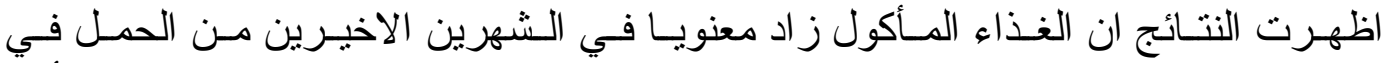

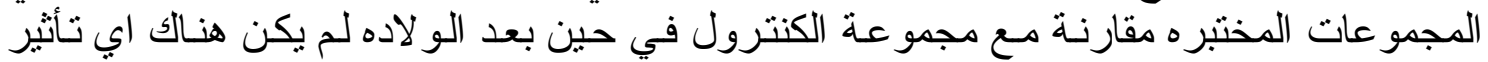

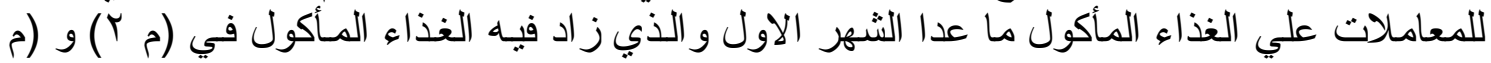

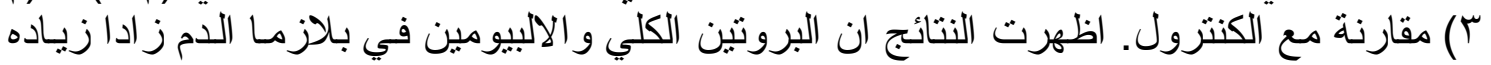

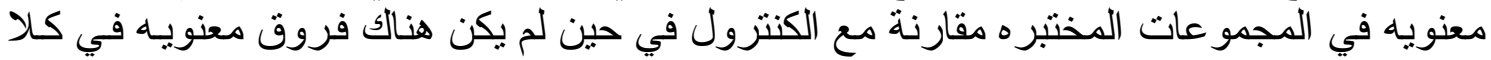

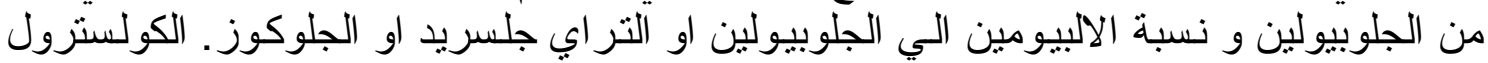

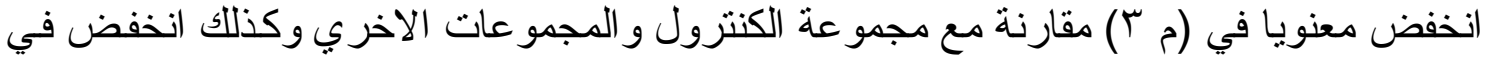

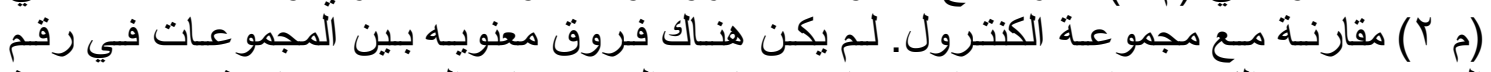

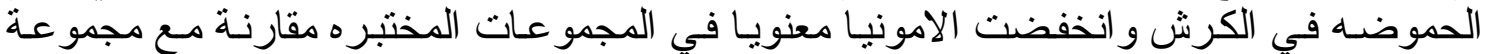

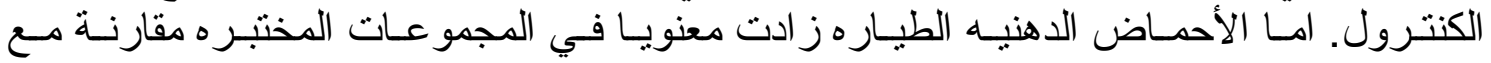
مجمو عة الكنترول. 